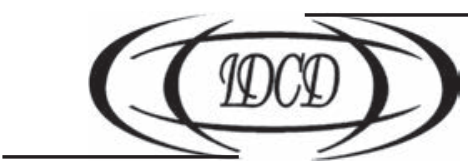

Doi: https://doi.org/10.15407/dse2018.01.058

УДК 330.59:316.34

JEL CLASSIFICATION: E25, O15

\title{
Г.Ю. МІЩУК
}

д-р екон. наук, проф.

Національний університет водного господарства

та природокористування

33028, м. Рівне, вул. Соборна, 11

E-mail: mischuk_galina@ukr.net

\section{Н.М. САМОЛЮК}

канд. екон. наук, доц.

Національний університет водного господарства

та природокористування

33028, м. Рівне, вул. Соборна, 11

E-mail:n.m.samoliuk@nuwm.edu.ua

\section{ВИМІРЮВАННЯ СОЦІАЛЬНОЇ СПРАВЕДЛИВОСТІ У КОНТЕКСТІ ОЦІНКИ ЕФЕКТИВНОСТІ ВІДНОСИН РОЗПОДІЛУ В СУСПІЛЬСТВІ}

Для вимірювання соціальної справедливості запропоновано використовувати інтегральний показник, розроблений на підставі фундаментальних принципів теорії справедливості. Його складовими є два часткових показника, що характеризують рівень дотримання основних прав і розподілу соціальноекономічних досягнень. Визначено рівень соціальної справедливості в Україні та двох групах країн Європейського Союзу з очевидними та сформованими тенденціями економічного розвитку й ефективності соціальної політики: група лідерів (ВНД на душу населення вище середнього рівня, а нерівність доходів нижче від середньої за вищого податкового навантаження) та група країн, в яких якість регулювання економічних та соціальних процесів нижча за середню в СС. Установлено, що економічне лідерство країн має тісний зв'язок із соціальною справедливістю у суспільстві як щодо забезпечення базових прав, так і в розподілі соціально-економічних надбань. Орієнтація та забезпечення ефективності державної дистрибутивної політики у доступності соціально-економічних надбань понад мінімальні соціальні гарантії поки що поступається зусиллям щодо гарантування базових прав та свобод. Запропонована методика дає можливість з'ясувати резерви удосконалення державних дистрибутивних механізмів із урахуванням часткових індикаторів соціальної справедливості. Порівняння з лідерами за рівнем економічного та соціального розвитку дало змогу виявити першочергову потребу запровадження європейського досвіду забезпечення соціальної справедливості за правами людини, рівень дотримання яких в Україні є критично низьким: права власності, можливості захисту своїх прав у незалежній судовій системі, позбавлення корумпованості на всіх рівнях (враховано в поширеності хабарів та неофіційних платежсів). У числі пріоритетних дій щодо справедливого розподілу соціально-економічних надбань нагальними завданнями $\epsilon$ забезпечення ефективності правової системи вирішення суперечок та розвиненість фінансових послуг.

(С МІЩУК Г.Ю., САМОЛЮК Н.М., 2018 
Ключові слова: справедливість, базові права, економічні і соціальні надбання, індекс соціальної справедливості.

\title{
Г.Ю. Мищук
}

д-р экон. наук, проф.

Национальный университет водного хозяйства и природопользования

33028, г. Ровно, ул. Соборная, 11

E-mail: mischuk_galina@ukr.net

\section{Н.Н. Самолюк}

канд. экон. наук, доц.

Национальный университет водного хозяйства и природопользования

33028, г. Ровно, ул. Соборная, 11

E-mail: n.m.samoliuk@nuwm.edu.ua

\section{ИЗМЕРЕНИЕ СОЦИАЛЬНОЙ СПРАВЕДЛИВОСТИ В КОНТЕКСТЕ ОЦЕНКИ ЭФФЕКТИВНОСТИ ОТНОШЕНИЙ РАСПРЕДЕЛЕНИЯ В ОБЩЕСТВЕ}

\begin{abstract}
Для измерения социальной справедливости предложено использовать интегральный показатель, разработанный на основе фундаментальных принципов теории справедливости. Он состоит из двух частичных показателей, характеризирующих уровень соблюдения основных прав и распределения социально-экономических достижений. Определен уровень социальной справедливости в Украине и двух группах стран Европейского Союза со сформированными тенденциями экономического развития и эффективности социальной политики: группа лидеров (ВНД на душу населения выше среднего, а неравенство доходов ниже среднего при высокой налоговой нагрузке) и группа стран, в которых качество регулирования экономических и социальных процессов ниже среднего в ЕС. Установлено, что экономическое лидерство стран имеет тесную связь с социальной справедливостью в обществе как в части обеспечения базовых прав, так и в распределении социально-экономических достижений. Ориентация и обеспечение эффективности государственной дистрибутивной политики в доступности социально-экономических достижений выше минимальных социальных гарантий пока уступает усилиям по обеспечению основных прав и свобод. Предложенная методика дает возможность выявить резервы совершенствования государственных дистрибутивных механизмов с учетом частичных индикаторов социальной справедливости. Осуществленные сравнения с лидерами по уровню экономического и социального развития позволили определить первоочередную потребность внедрения европейского опыта обеспечения социальной справедливости в разрезе прав человека, уровень соблюдения которых в Украине критически низок: права собственности, возможности зашиты своих прав в независимой судебной системе, искоренение коррумпированности на всех уровнях (учтено в распространении взяток и неофициальных платежей). В числе приоритетных действий относительно справедливого распределения социально-экономических достижений неотложными заданиями являются обеспечение эффективности правовой системы разрешения споров и развитость финансовых услуг.
\end{abstract}

Ключевые слова: справедливость, базовые права, экономические и социальные достижения, индекс социальной справедливости.

\section{H.Yu. Mishchuk}

Dr. Sc. (Economics), Prof.

National University of Water and Environmental Engineering

33028, Ukraine, Rivne, Soborna str., 11

E-mail: mischuk_galina@ukr.net

\section{N.M. Samoliuk}

PhD (Economics), Associate Prof

National University of Water and Environmental Engineering

33028, Ukraine, Rivne, Soborna str., 11

E-mail: n.m.samoliuk@nuwm.edu.ua 


\section{MEASURING SOCIAL JUSTICE IN THE CONTEXT OF ASSESSMENT OF DISTRIBUTIVE RELATIONS EFFECTIVENESS IN SOCIETY}

In order to measure social justice the paper proposes using an integral indicator developed on the basis of the fundamental principles of the theory of justice. It includes two partial indicators that characterize the level of ensuring fundamental rights and the distribution of socio-economic achievements. In our research we identify the level of social justice on the example of Ukraine and two groups of European Union countries with the most evident and formed trends of economic development and social policy efficiency: a group of leaders (economies with GNI per capita that is higher than the average and income inequality that is below the average even with high tax burden), and a group of countries in which the quality of economic and social regulation processes is lower than the average level in EU. As a consequence it was found that economic leadership of the countries has a close connection with social justice in society both for ensuring of fundamental rights and for the distribution of socio-economic achievements. It was also proved that targeting and ensuring the effectiveness of the state distribution policy in the availability of socio-economic assets beyond the minimum social guarantees is still inferior to efforts to guarantee basic rights and freedoms. The proposed method makes it possible to identify the reserves for the improvement of state distribution mechanisms considering partial indicators of social justice. Comparisons with the leaders in terms of economic and social development reveal the urgent need for the implementation of European experience of social justice ensuring human rights which are observed on a critically low level in Ukraine: property rights, protection of rights in an independent judicial system, freedom from corruption on all levels (it is considered in the wide spread of bribes and unofficial payments). It was also proved that among the priority actions for the equitable distribution of socio-economic achievements the urgent tasks are ensuring the effectiveness of the legal system for resolving disputes and the development of financial services.

Keywords: justice, basic rights, economic and social assets, index of social justice.

Постановка проблеми. Соціальна справедливість є загальновизнаною цінністю сучасного демократичного суспільства, про що йдеться в низці міжнародних документів. Зокрема, у резолюції № 62/10 від 26.11.2007 Генеральна Асамблея ООН визнала, що соціальний розвиток і соціальна справедливість необхідні для забезпечення та підтримання миру і безпеки всередині країн і у відносинах між ними. При цьому соціальний розвиток і соціальна справедливість не можуть бути досягнуті в умовах відсутності поваги до всіх прав та основних свобод людини [1]. Міжнародна організація праці 10.08.2008 одноголосно ухвалила Декларацію про соціальну справедливість, в якій наголошено на гарантуванні досягнення справедливих результатів через посередництво у забезпеченні зайнятості, соціального захисту, соціального діалогу та основоположних принципів і прав на робочому місці [2].

Найчастіше справедливість є об’єктом вивчення соціологів, які оцінюють іiі на основі власних підходів до формування анкет. У зв'язку із цим використовувати отримані результати як постійну основу відповідних досліджень і враховувати їх для прийняття економічних рішень неможливо. Тому для формування співставних масивів даних, що могли б бути основою вивчення впливу факторів справедливості на економічні наслідки, а також оцінки ефективності державної політики розподілу суспільних благ, доцільно уніфікувати підходи до вимірювання рівня задоволеності дотриманням прав за різними напрямами взаємодії у суспільстві, що і є суттю справедливості. Перенесення морально-етичних і правових засад філософського, психологічного та соціологічного розуміння справедливості у площину економічних відносин потребує уточнення складових оцінювання, що на даний час є надзвичайно актуальним.

Аналіз останніх досліджень і публікацій. Сучасні західні теорії справедливості розглядають їі відносно окремої особистості. Тривалий час в економічній науці домінувала утилітаристська концепція, згідно з якою справедливість полягала у максимізації загальної корисності всіх членів суспільства. Значним досягненням у 
дослідженні соціальної справедливості є робота Дж. Ролса (J. Rawls) [3], якою закладено фундаментальні засади аналізу справедливості шляхом урахування дотримання конституційних свобод. За таким підходом, мінімальним рівнем справедливості можна вважати дотримання базових прав людини, що сьогодні визнані світовою спільнотою у Загальній декларації людських прав [4].

Розвиваючи концепцію Дж. Ролса, нобелівський лауреат Дж. Стігліц (J. Stiglitz) відмітив, що в інтересах соціальної справедливості базові права повинні бути доповнені економічними правами. Він змістив акцент проблеми справедливості на рівність можливостей і звернув увагу на позитивний зв'язок між рівністю можливостей та економічною ефективністю: «Більша рівність можливостей означає, що країна буде краще використовувати свої основні людські ресурси, забезпечивши кожному умови для повного використання власного потенціалу. Підвищаться і ефективність, і справедливість розподілу» [5]. Дана концепція була підтримана і доведена до ієрархії прав і свобод, які треба забезпечувати для досягнення соціальної справедливості, російськими вченими Б.А. Ефимовим (B. Efimov) та Г.Г. Пироговим (G. Pirogov) [6].

У працях Д.C. Львова (D. Lvov) висунуто принципово нову концепцію справедливості. На його думку, досягти високого рівня справедливості неможливо без зміни основної парадигми існування, зокрема ролі суспільства у досягненні справедливості: «Прагнення до багатства і його символічного вираження - прагненням до високої якості життя, якої неможливо досягти індивідуально, не підвищуючи одночасно якості життя інших» [7]. Ця концепція узгоджується з концепцією соціально відповідальної держави, викладеної у працях О.А. Грішнової (O. Hrishnova), зокрема в монографіï [8].

Різні аспекти соціальної справедливості розглянуто також у працях інших вітчизняних вчених. Зокрема, E.M. Лібанова (Е. Libanova) розглядає справедливість як чинник узгодження короткострокових та довгострокових імперативів розвитку суспільства [9]. А.М. Гриненко (А. Hrynenko) вивчає «соціальну справедливість» в аспекті реалізації соціальної політики [10]. А.А. Гриценко (A. Hrytsenko) розглядає справедливість у контексті стійкого економічного розвитку, можливого на засадах поєднання ефективних відносин розподілу та взаємодії у суспільстві (концепція сумісно-розділеної діяльності) [9]. В.М. Новіков (V. Novikov) досліджує вплив функціональної концепції справедливості на поведінку людей і соціогуманітарний розвиток [11].

Сучасні трактування справедливості значною мірою відійшли від традиційних для утилітаристів поглядів щодо потреби максимізації загальної корисності. Демократичні цінності значною мірою є надбанням ліберальної економічної думки. У наукових дослідженнях вони втілюються у концепції сильної соціальної ролі держави через «дистрибутивну справедливість». Саме ця ідея, починаючи з праці Дж. Ролса становить сьогодні основу більшості удосконалених тлумачень справедливості. Точніше, об’єктом аналізу сьогодні уже є не справедливість як така, а фактори, які можна задіяти для формування комфортних стосунків у суспільстві, відчуття задоволеності як принципами справедливості, так і методами, якими вона забезпечується.

Іншою помітною особливістю сучасних концепцій справедливості є те, що жоден із авторів не конкретизує «сигнальних точок», після досягнення яких несправедливість стає не просто соціальним злом, а потужним деструктивним механізмом у економічних процесах. Задля зменшення негативних впливів несправедливості у різних її проявах, передусім надмірної нерівності доходів, гендерних, вікових та інших асиметрій у забезпеченні доступності суспільних благ, панівним є підхід дослідників 
до аналізу регуляторного впливу держави на різних рівнях. При цьому дуже рідко дослідники пропонують чіткі механізми або інструменти впливу на нерівність.

3 наведених ключових ідей аналізу справедливості, що сьогодні становлять основу оцінок нерівності доходів, очевидно, що більшість авторів оминають питання граничних меж несправедливості, визнаючи такими тільки ті, що суперечать правам людини. Інші ж принципи, що дають змогу справедливо розподіляти цінності вищого порядку, повинні визначатись кожним суспільством відповідно до принципів, погоджених на основі суспільного діалогу (договору), наприклад, у межах базового рівня справедливості гарантується право на працю, але встановлення справедливих пропорцій в оплаті праці з урахуванням іiі умов та кваліфікаційних вимог повинно відображати суспільну логіку розуміння справедливості в установленні меж нерівності доходів. Такі допустимі межі залежать не лише від фундаментальних економічних законів та об'єктивних суспільних потреб, а й від суб’єктивних оцінок справедливості, які не можуть бути визначені інакше, ніж шляхом соціологічних опитувань, що нині є узвичаєною практикою для мікрорівневого аналізу.

3 огляду на викладене, метою статті є удосконалення методології оцінки соціальної справедливості та статистична апробація можливості їі використання для аналізу ефективності державної політики розподілу на прикладі України та європейських країн зі сформованими залежностями результатів економічного розвитку та соціальної політики.

Науковою новизною даної роботи є розвиток методології оцінювання соціальної справедливості з обгрунтуванням ії комплексного індикатора, що дає змогу врахувати вплив таких часткових складових, як дотримання базових прав людини та розподіл соціально-економічних надбань суспільства.

Виклад основного матеріалу. Беззаперечним на сьогодні є розуміння справедливості як дотримання базових прав людини, що забезпечує базовий, мінімально необхідний ііі рівень, за якого можлива безконфліктна взаємодія у суспільстві. Такий підхід, крім ідей Дж. Ролса щодо обов'язкового гарантування прав і соціальної підтримки найвразливіших верств населення, визнаний людством в одному з основних міжнародних документів [4]. Проте такий рівень соціальної справедливості уже не відповідає сучасній ролі держави та вимогам до неї з боку суспільства. Тому ще одним компонентом оцінки має бути характеристика дистрибутивної справедливості у доступності благ вищого рівня - соціальні та економічні надбання певного суспільства, що перевищують мінімально необхідний «пакет» соціальних гарантій держави, базовий рівень ііі соціальної відповідальності. До вивчення цієї складової у науковій літературі немає загальноприйнятих підходів. Для прикладу, Дж. Стігліц [5] пише про доповнення базових прав економічними, але їх уточнення не наводить.

У зв’язку з цим варто визначати рівень соціальної справедливості на основі агрегатного індексу, побудованого з урахуванням розмежування суспільних відносин за рівнем відповідальності держави щодо благополуччя своїх громадян. Складові часткових індексів, врахованих у загальному індексі соціальної справедливості (ICC), характеризують рівень дотримання базових прав та свобод людини, гарантованих державою, і справедливість розподілу економічних та соціальних надбань суспільства понад ті, що забезпечує держава:

$$
\mathrm{ICC}=\alpha\left(\sum_{\mathrm{i}=1}^{\mathrm{n}} \mathrm{I}_{\Pi_{\mathrm{i}}} / \mathrm{n}\right)+\beta\left(\sum_{\mathrm{j}=1}^{\mathrm{m}} \mathrm{I}_{\mathrm{Hj}} / \mathrm{m}\right)
$$


де ICC - індекс соціальної справедливості; $I_{\text {п }}$ - індекс доступності базових прав; $I_{\text {н }}$ - індекс справедливості розподілу економічних і соціальних надбань; $\alpha$ - вага часткового індексу доступності базових прав; $\beta$ - вага часткового індексу справедливості розподілу економічних і соціальних надбань; $n, m-$ кількість складових оцінки у відповідних часткових індексах.

Сума ваги часткових індексів а і $\beta$ дорівнює одиниці. Їх співвідношення підлягає коригуванню і може встановлюватися в результаті наукових дискусій, переговорів соціальних партнерів на різних рівнях та іншим чином. Зокрема, можна скористатися досвідом побудови індексу глобальної конкурентоспроможності, коли для встановлення ваги часткових індексів враховують етапи економічного розвитку країн: велика питома вага надається складовим, важливішим для поточного етапу економічного розвитку певної країни. Наприклад, для країн із дуже високим рівнем людського розвитку а може бути значно меншим за $\beta$, адже переважно базових прав і свобод у цих країнах дотримуються, і навпаки.

Способи розрахунку часткових індексів ICC залежно від завдань дослідження можуть бути різними. Зокрема, для ранжування і визначення ICC у межах певного діапазону забезпечення справедливості в європейських країнах найбільш прийнятним $є$ підхід, за якого еталоном $є$ максимальне значення конкретної компоненти оцінювання суспільної справедливості:

$$
I_{\Pi_{i}}=\frac{Q_{f_{i}}-Q_{\min _{i}}}{Q_{\max _{i}}-Q_{\min _{i}}} \quad(2) ; \quad I_{H_{j}}=\frac{Q_{f_{j}}-Q_{\min _{j}}}{Q_{\max _{j}}-Q_{\min _{j}}}
$$

де $\mathrm{Q}_{\mathrm{fi}}, \mathrm{Q}_{\mathrm{fj}}$ - фактичні значення окремих складових часткових індексів; $\mathrm{Q}_{\operatorname{mini}}$, $\mathrm{Q}_{\text {minj }}-$ мінімальні значення окремих складових часткових індексів; $\mathrm{Q}_{\text {maxi }}$, $\mathrm{Q}_{\text {maxj }}$ - максимальні значення окремих складових часткових індексів.

Однак, якщо у складі часткових компонентів справедливості є стимулятори та дестимулятори, їх нормалізацію здійснюють за різними формулами: (4) для стимуляторів та (5) для де стимуляторів. Нижче приклад наведено для субіндексу доступності базових прав, аналогічно розрахунок здійснюється для розподілу соціальних надбань:

$$
\mathrm{I}_{\Pi_{\mathrm{i}}}^{+}=\frac{\mathrm{Q}_{f_{\mathrm{i}}}-\mathrm{Q}_{\min _{\mathrm{i}}}}{\mathrm{Q}_{\max _{\mathrm{i}}}-\mathrm{Q}_{\min \mathrm{i}}} \quad(4) ; \quad \mathrm{I}_{\Pi_{\mathrm{i}}}^{-}=\frac{\mathrm{Q}_{\max _{\mathrm{i}}}-\mathrm{Q}_{\mathrm{f}_{\mathrm{i}}}}{\mathrm{Q}_{\max _{\mathrm{i}}}-\mathrm{Q}_{\min _{\mathrm{i}}}}
$$

На рис. 1. показано деякі складові часткових індексів, що можуть бути використані для оцінювання соціальної справедливості. Компоненти оцінки справедливості у доступності базових прав та свобод формувалися на основі Загальної декларації прав людини. Вони можуть бути визначені на основі статистичних даних різних міжнародних і національних досліджень, принаймні, в аспекті порушень, виявлених міжнародними моніторинговими організаціями. Склад компонентів оцінки справедливості розподілу економічних і соціальних надбань є продовженням концепції дистрибутивної справедливості в аналізі справедливості розподілу суспільних благ чи доступу до них. Деякі індикатори цього часткового індексу доцільно доповнювати даними, отриманими в результаті соціологічних обстежень різних об’єктів дослідження, що хоч і ускладнює розрахункові процедури, але дає змогу точніше виявляти чутливість суспільства до регуляторних дій у державній політиці розподілу. 


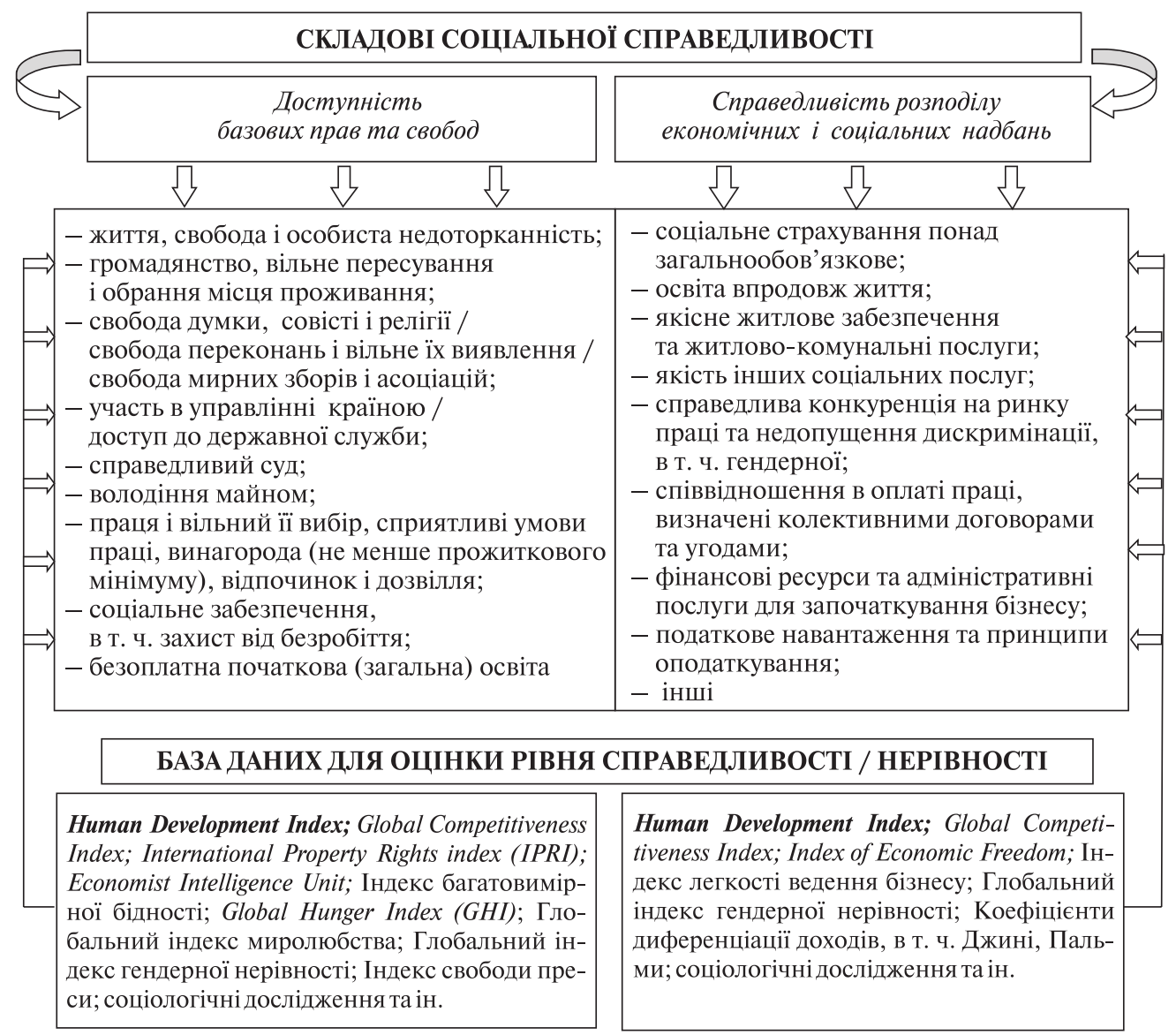

Рис. 1. Компоненти соціальної справедливості та інформаційна база її оцінювання

Джерело: розробка авторів.

Для експрес-аналізу справедливості, якщо за мету ставиться не абсолютно точне відтворення суспільного сприйняття дотримання прав, а виявлення загальних закономірностей і міжнародних відмінностей в управлінні людськими ресурсами, інформаційною базою розрахунку можуть бути складові загальновідомих індексів, наведені на рис. 1. Точніша оцінка рівня справедливості потребує масштабних соціологічних опитувань за частиною часткових індикаторів.

У даній роботі аналіз та порівняння якості державної політики розподілу у різних Європейських країнах здійснено на основі спрощеного методологічного підходу без соціологічних опитувань і врахування їх результатів. Комплекс складових ІСС трансформовано відповідно до цілей дослідження, подальший аналіз виконано на основі складу індикаторів, що достатньо повно ілюструють основні компоненти соціальної справедливості державних механізмів розподілу. Необхідні компоненти, з урахуванням логіки розподілу індикаторів за напрямами відповідальності держави (мінімально необхідні гарантії справедливості та розподіл додаткових соціально-економічних благ), виділено зі складових Індексу глобальної конкурентоспроможності (IГК) - вони, разом із позначеннями за відповідним блоком оцінки конкурентоспроможності, наведені в табл. 1. 
Таблиия 1. Складові соціальної справедливості (за ІГК)

\begin{tabular}{|c|c|c|c|}
\hline $\begin{array}{l}\text { Складові } \\
\text { ICC }\end{array}$ & $\begin{array}{l}\text { Доступність базових прав } \\
\text { та свобод }\end{array}$ & $\begin{array}{l}\text { Складові } \\
\text { ICC }\end{array}$ & $\begin{array}{c}\text { Справедливість розподілу економічних } \\
\text { і соціальних надбань }\end{array}$ \\
\hline 1.01 & Право власності & 1.10 & $\begin{array}{l}\text { Ефективність правової системи в урегулю- } \\
\text { ванні суперечок }\end{array}$ \\
\hline 1.05 & $\begin{array}{l}\text { Хабарі та неофіційні } \\
\text { платежі }\end{array}$ & 2.01 & Якість загальної інфраструктури \\
\hline 1.06 & $\begin{array}{l}\text { Незалежність судової } \\
\text { системи }\end{array}$ & 5.01 & Охоплення населення середньою освітою \\
\hline 1.16 & $\begin{array}{l}\text { Надійність роботи право- } \\
\text { охоронних органів }\end{array}$ & 5.02 & Охоплення населення вищою освітою \\
\hline 4.03 & $\begin{array}{l}\text { Захворюваність на тубер- } \\
\text { кульоз }\end{array}$ & 5.03 & Якість системи освіти \\
\hline 4.05 & Поширеність ВІЛ & 5.08 & Підвищення кваліфікації персоналу \\
\hline 4.07 & Дитяча смертність & 7.01 & $\begin{array}{l}\text { Співпраця у відносинах працівник - пра- } \\
\text { цедавець }\end{array}$ \\
\hline 4.08 & $\begin{array}{l}\text { Середня очікувана трива- } \\
\text { лість життя }\end{array}$ & 7.02 & Гнучкість при встановленні зарплатні \\
\hline 4.09 & Якість початкової освіти & 7.05 & $\begin{array}{l}\text { Вплив оподаткування на бажання працю- } \\
\text { вати }\end{array}$ \\
\hline \multirow[t]{4}{*}{4.10} & \multirow{4}{*}{$\begin{array}{l}\text { Охоплення населення по- } \\
\text { чатковою освітою }\end{array}$} & 7.06 & Оплата праці та продуктивність \\
\hline & & 7.10 & Частка жінок у робочій силі \\
\hline & & 8.01 & Наявність фінансових послуг \\
\hline & & 8.02 & Доступність фінансових послуг \\
\hline
\end{tabular}

Джерело: складено авторами на основі даних Global Competitiveness Report [12].

Вибір країн ЄС для порівняння ефективності дистрибутивної політики в соціально-економічній сфері здійснено за методикою, викладеною в одній із попередніх наших робіт [13]. Аналіз ефективності механізмів регуляторного впливу виконано на прикладі двох груп країн із чітко окресленими та сформованими тенденціями економічного та соціального розвитку:

- груnа 1 - країни, які за високого податкового навантаження мають ВНД на душу населення вище середнього та нерівність доходів нижче середньої;

- група 2 - країни, які за низького податкового навантаження мають ВНД на душу населення нижче за середній та нерівність доходів вище за середню.

Для групування країн використано дані міжнародних звітів 2016 Index of Economic Freedom [14] та Human Development Report 2016 [15], за якими середній ВНД на душу населення становить 35517 дол США, середній рівень нерівності - 16,2 \%, а середнє податкове навантаженням - 35,1\%.

На підставі попереднього аналізу до групи 1, де соціально-економічна ефективність за названими критеріями є вищою за середню в СС, належать: Фінляндія, Нідерланди, Швеція, Бельгія, Данія, Люксембург, Німеччина. До групи 2 (соціально-економічна ефективність нижча за середню в (С) увійшли: Естонія, Португалія, Литва, Латвія, Польща, Болгарія, Греція, Хорватія, Румунія. Рівень соціальної справедливості у цих групах країн порівняно з рівнем в Україні. 


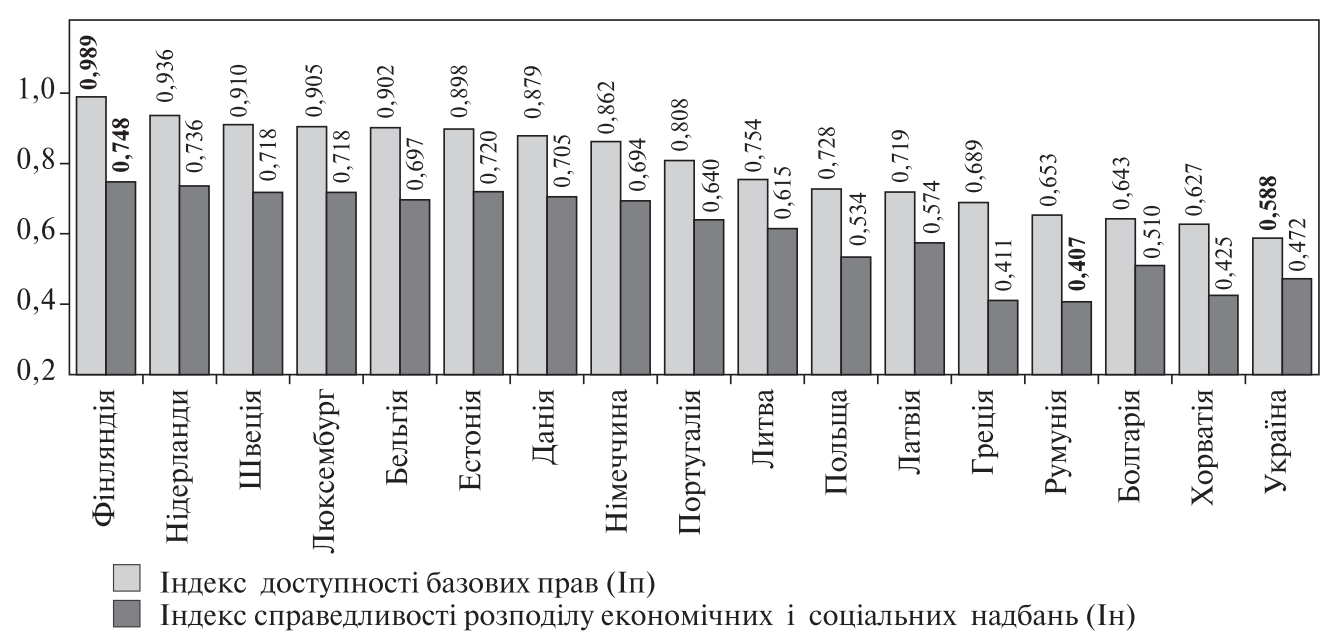

Рис. 2. Часткові індекси ICС в Україні та країнах СС у 2016 р.

Джерело: побудовано авторами на основі даних Global Competitiveness Report [12].

Розрахунок часткових індексів ICС здійснено за формулами $(2,3)$ з попередньою нормалізацією значень факторів за формулами $(4,5)$, адже серед складових часткових індексів наявні дестимулятори, а саме: «Дитяча смертність», «Захворюваність на туберкульоз», «Поширеність ВІЛ» (табл. 1). Мінімальні $\left(\mathrm{Q}_{\min }\right)$ та максимальні $\left(\mathrm{Q}_{\max }\right)$ значення складових часткових індексів вибрано з показників 138 країн, включених у Global Competitiveness Report 2016-2017 [12].

Результати розрахунку часткових індексів проілюстровані на рис. 2. Як бачимо, найвищий рівень обох субіндексів має Фінляндія, найгірший стан доступності базових прав спостерігається в Україні, а найменша справедливість у розподілі економічних та соціальних надбань - у Румунії.

Сьогодні уже очевидним є те, що навіть у межах ЄС існують суттєві відмінності в сприйнятті та суспільній підтримці ідей соціальної відповідальності держави, особливо щодо її спрямованості за окремими векторами державного регулювання процесів розподілу. Це підтверджують і отримані нами результати (рис. 2). В основу даного дослідження покладено переконання, що реалії розвитку соціально-економічних систем не можуть нівелювати ідеї забезпечення соціально справедливого середовища життя та праці в певній країні. Проте апробовані тривалою практикою суспільних відносин відмінні для різних країн межі, за якими відносини сприймаються як такі, що порушують справедливість, вимагають наближення методології оцінки справедливості до властивих певному суспільству принципів взаємодії, особливо в площині відносин із державою. Тому, розрахунок рівня соціальної справедливості ми виконали з урахуванням різних підходів до розуміння ролі держави:

• акцент на соціальній підтримці та обов’язковому гарантуванні лише базових прав;

• більша вагомість складової, що характеризує ефективність зусиль у дистрибуції додаткових благ. У цьому випадку припущено, що в сучасному світі базовий блок має бути гарантований безумовно і не потребує встановлення високої вагомості в інтегральному показнику, а розраховується лише з формальномоніторинговими цілями. 
З огляду на викладене, ICC розраховано за чотирма різними варіантами значень вагових коефіцієнтів:

1) без урахування вагомості окремих факторів, із припущенням однакової важливості кожної складової та з визначенням ICC за методом середньої арифметичної простої;

2) за умови рівної важливості обох блоків індикаторів соціальної справедливості $(\alpha=\beta=0,5)$;

$3)$ з більшою вагомістю дотримання базових прав людини $(\alpha=0,7 ; \beta=0,3)$;

4) з більшою вагомістю справедливості у розподілі соціально-економічних надбань суспільства $(\alpha=0,3 ; \beta=0,7)$ (табл. 2$)$.

За всіма варіантами розрахунку простежується лідерство семи країн, які вирізняються найвищою економічною результативністю та найменшою нерівністю розподілу доходів. Однак нетиповим прикладом високої соціальної справедливості за нижчих офіційних економічних успіхів є досвід гарантування прав громадян та політики розподілу в Естонії - іï значення за всіма способами розрахунку знаходяться практично на рівні Швеції. Таке суттєве випередження якості державного регулювання відносин розподілу може бути ознакою економіки, яка швидко зростає і в якій створена ефективна державна інфраструктура підтримки та стимулювання розвитку громадян, залучення їх до активної участі в суспільних процесах. Найімовірніше це призведе до лідерських позицій і в інших макроекономічних показниках, формування яких має лаговий ефект.

Таблиия 2. Індекс соціальної справедливості для України та країн ЕС, 2016 р.

\begin{tabular}{|c|c|c|c|c|c|}
\hline \multirow[t]{2}{*}{ Група } & \multirow[t]{2}{*}{ Країна } & \multicolumn{4}{|l|}{ ICC } \\
\hline & & Без врахування вагових коефіцієнтів & $\begin{array}{l}\alpha=0,5 \\
\beta=0,5\end{array}$ & $\begin{array}{c}\alpha=0,7 \\
\beta=0,3\end{array}$ & $\begin{array}{l}\alpha=0,3 \\
\beta=0,7\end{array}$ \\
\hline \multirow[t]{7}{*}{1} & Фінляндія & 0,853 & 0,869 & 0,917 & 0,820 \\
\hline & Нідерланди & 0,823 & 0,836 & 0,876 & 0,796 \\
\hline & Швеція & 0,802 & 0,814 & 0,852 & 0,776 \\
\hline & Бельгія & 0,786 & 0,800 & 0,841 & 0,759 \\
\hline & Данія & 0,781 & 0,792 & 0,827 & 0,757 \\
\hline & Люксембург & 0,799 & 0,812 & 0,849 & 0,774 \\
\hline & Німеччина & 0,767 & 0,778 & 0,812 & 0,745 \\
\hline \multirow[t]{9}{*}{2} & Естонія & 0,797 & 0,809 & 0,844 & 0,774 \\
\hline & Португалія & 0,713 & 0,724 & 0,758 & 0,690 \\
\hline & Литва & 0,675 & 0,684 & 0,712 & 0,656 \\
\hline & Латвія & 0,637 & 0,646 & 0,675 & 0,617 \\
\hline & Польща & 0,618 & 0,631 & 0,670 & 0,592 \\
\hline & Болгарія & 0,568 & 0,576 & 0,603 & 0,550 \\
\hline & Греція & 0,532 & 0,550 & 0,605 & 0,494 \\
\hline & Хорватія & 0,513 & 0,526 & 0,566 & 0,486 \\
\hline & Румунія & 0,514 & 0,530 & 0,579 & 0,480 \\
\hline \multicolumn{2}{|l|}{ Україна } & 0,522 & 0,530 & 0,553 & 0,507 \\
\hline
\end{tabular}

Джерело: складено авторами на основі даних Global Competitiveness Report [12]. 
МІЩУК Г.Ю., САМОЛЮК Н.М.

Таблиия 3. Розрахунок ICC на основі складових ІГК для України та Фінляндії

\begin{tabular}{|c|c|c|c|c|c|c|}
\hline \multirow[t]{2}{*}{$\begin{array}{l}\text { Складові } \\
\text { ICC }\end{array}$} & \multirow[t]{2}{*}{$\mathbf{Q}_{\max }$} & \multirow[t]{2}{*}{$\mathbf{Q}_{\min }$} & \multicolumn{2}{|c|}{$\mathbf{Q}_{\mathrm{f}}$} & \multicolumn{2}{|c|}{$\begin{array}{c}\text { Часткові індекси соціальної } \\
\text { справедливості }\end{array}$} \\
\hline & & & Фінляндія & Україна & Фінляндія & Україна \\
\hline \multicolumn{5}{|c|}{ Доступність базових прав та свобод } & \multicolumn{2}{|c|}{$\mathbf{I}_{\mathrm{ni}}$} \\
\hline 1.01 & 6,50 & 1,60 & 6,50 & 3,00 & 1,000 & 0,286 \\
\hline 1.05 & 6,80 & 1,90 & 6,80 & 2,90 & 1,000 & 0,204 \\
\hline 1.06 & 6,70 & 1,10 & 6,70 & 2,30 & 1,000 & 0,214 \\
\hline 1.16 & 6,80 & 1,90 & 6,80 & 3,50 & 1,000 & 0,327 \\
\hline 4.03 & 852,00 & 0,90 & 5,60 & 94,00 & 0,994 & 0,891 \\
\hline 4.05 & 25,20 & 0,00 & 0,10 & 1,20 & 0,996 & 0,952 \\
\hline 4.07 & 87,10 & 1,50 & 1,90 & 7,70 & 0,995 & 0,928 \\
\hline 4.08 & 84,00 & 49,70 & 81,10 & 71,20 & 0,915 & 0,627 \\
\hline 4.09 & 6,70 & 2,00 & 6,70 & 4,40 & 1,000 & 0,511 \\
\hline 4.10 & 100,00 & 37,70 & 99,40 & 96,20 & 0,990 & 0,939 \\
\hline \multicolumn{5}{|c|}{ Справедливість розподілу економічних і соціальних надбань } & \multicolumn{2}{|c|}{$I_{\mathrm{Hi}}$} \\
\hline 1.10 & 6,20 & 1,60 & 5,70 & 2,80 & 0,891 & 0,261 \\
\hline 2.01 & 6,50 & 1,60 & 6,10 & 3,60 & 0,918 & 0,408 \\
\hline 5.01 & 164,80 & 22,40 & 145,50 & 99,20 & 0,864 & 0,539 \\
\hline 5.02 & 110,20 & 0,80 & 88,70 & 82,30 & 0,803 & 0,745 \\
\hline 5.03 & 6,20 & 2,00 & 5,70 & 4,00 & 0,881 & 0,476 \\
\hline 5.08 & 5,70 & 2,20 & 5,40 & 3,70 & 0,914 & 0,429 \\
\hline 7.01 & 6,20 & 2,50 & 5,20 & 4,20 & 0,730 & 0,459 \\
\hline 7.02 & 6,20 & 2,20 & 2,20 & 4,90 & 0,000 & 0,675 \\
\hline 7.05 & 6,30 & 2,20 & 3,30 & 3,00 & 0,268 & 0,195 \\
\hline 7.06 & 5,60 & 2,10 & 4,80 & 4,40 & 0,771 & 0,657 \\
\hline 7.10 & 1,11 & 0,22 & 0,97 & 0,83 & 0,843 & 0,685 \\
\hline 8.01 & 5,70 & 2,10 & 5,50 & 3,00 & 0,944 & 0,250 \\
\hline 8.02 & 6,00 & 2,30 & 5,60 & 3,60 & 0,892 & 0,351 \\
\hline \multicolumn{5}{|c|}{ ICC (без урахування вагових коефіцієнтів) } & 0,853 & 0,522 \\
\hline \multicolumn{5}{|c|}{$\operatorname{ICC}(\alpha=0,5 ; \beta=0,5)$} & 0,869 & 0,530 \\
\hline \multicolumn{5}{|c|}{$\operatorname{ICC}(\alpha=0,7 ; \beta=0,3)$} & 0,917 & 0,553 \\
\hline \multicolumn{5}{|c|}{$\operatorname{ICC}(\alpha=0,3 ; \beta=0,7)$} & 0,820 & 0,507 \\
\hline
\end{tabular}

Джерело: складено авторами на основі даних Global Competitiveness Report [12]. 
Водночас, як видно з табл. 2, жодна з країн не має ідеальних соціально справедливих умов для життя населення та економічного розвитку. Навіть Фінляндія з їі очевидним лідерством має резерви удосконалення дистрибутивної політики держави, передусім щодо розподілу тих суспільних благ, які прибічники теорії справедливості та основні нормативні акти у дотриманні прав людини не визнають обов'язковими для гарантування державою (враховано в індикаторах доступності базових прав і свобод).

Фактично в усіх досліджуваних країнах прослідковується ще одна закономірність: ICC є набагато вищим за умови врахування вищої вагомості складових блоку «Доступність базових прав та свобод». Даний факт свідчить про те, що навіть у розвинених країнах ЄС державне управління спрямоване більшою мірою на підтримку мінімальних соціальних стандартів і забезпечення основних прав та свобод громадян. Такий вектор державного регулювання соціально-економічної сфери значно переважає орієнтацію на забезпечення ефективної дистрибутивної політики щодо інших аспектів життя, які мають радше стимулювальний, а не підтримувальний вплив на суспільство.

3 метою виявлення резервів удосконалення регуляторних механізмів забезпечення соціальної справедливості здійснено детальніший розрахунок ICC України та Фінляндії - країни, що посідає позиції лідера серед країн ЄС за частковими індексами ICC (табл. 3).

Порівняння фактичних значень $\left(\mathrm{Q}_{\mathrm{f}}\right)$ складових часткових індексів України та Фінляндії засвідчує суттєву відмінність політики розподілу цих двох країн. Як бачимо з табл. 3, п’ять із десяти часткових індексів доступності базових прав ( $\left.\mathrm{I}_{п}\right)$ у Фінляндії досягли максимального значення і дорівнюють 1, а в Україні чотири показника не досягають навіть відмітки 0,5. Це означає, що у нас є значні резерви покращення ситуації з правом власності, якістю судової та правоохоронної системи. Водночас, в рази нижче значення часткових індексів наявності і доступності фінансових послуг в Україні порівняно з Фінляндією підтверджує зв'язок рівня справедливості середовища ведення бізнесу з економічними успіхами країн. Тож і в цьому напрямі в України є резерви зростання.

Звичайно, повне уявлення про ефективність державних програм забезпечення справедливості (в т. ч. справедливого розподілу доходів), можна скласти тільки на основі опрацювання більшого масиву інформації, наприклад, соціологічних оцінок задоволеності частковими аспектами справедливості. Але те, що відповідальність та ефективність держави у справедливому розподілі суспільних благ є ключовим рушієм побудови ефективної соціальної економіки - незаперечний факт. У зв'язку з цим автори підтримують ідею сильної держави у регулюванні соціальних процесів на відміну від ідей «мінімальної держави» з її втручанням виключно у чітко окреслені аспекти відносин, наприклад, дотримання «права на життя, на свободу, на власність» (J. Hospers) [16]. Для досягнення соціальної справедливості необхідно комплексно використовувати інструменти державного та договірного регулювання, що наведені на рис. 3.

Отже, саме соціально орієнтовані концепції справедливості із гнучким державним регулюванням податковими, монетарними, іншими важелями державного впливу на ринок праці, освітніх послуг, розподіл доходів і інших благ є тим вектором розвитку, ефективність якого доведена соціально-економічними успіхами розвинених країн. 


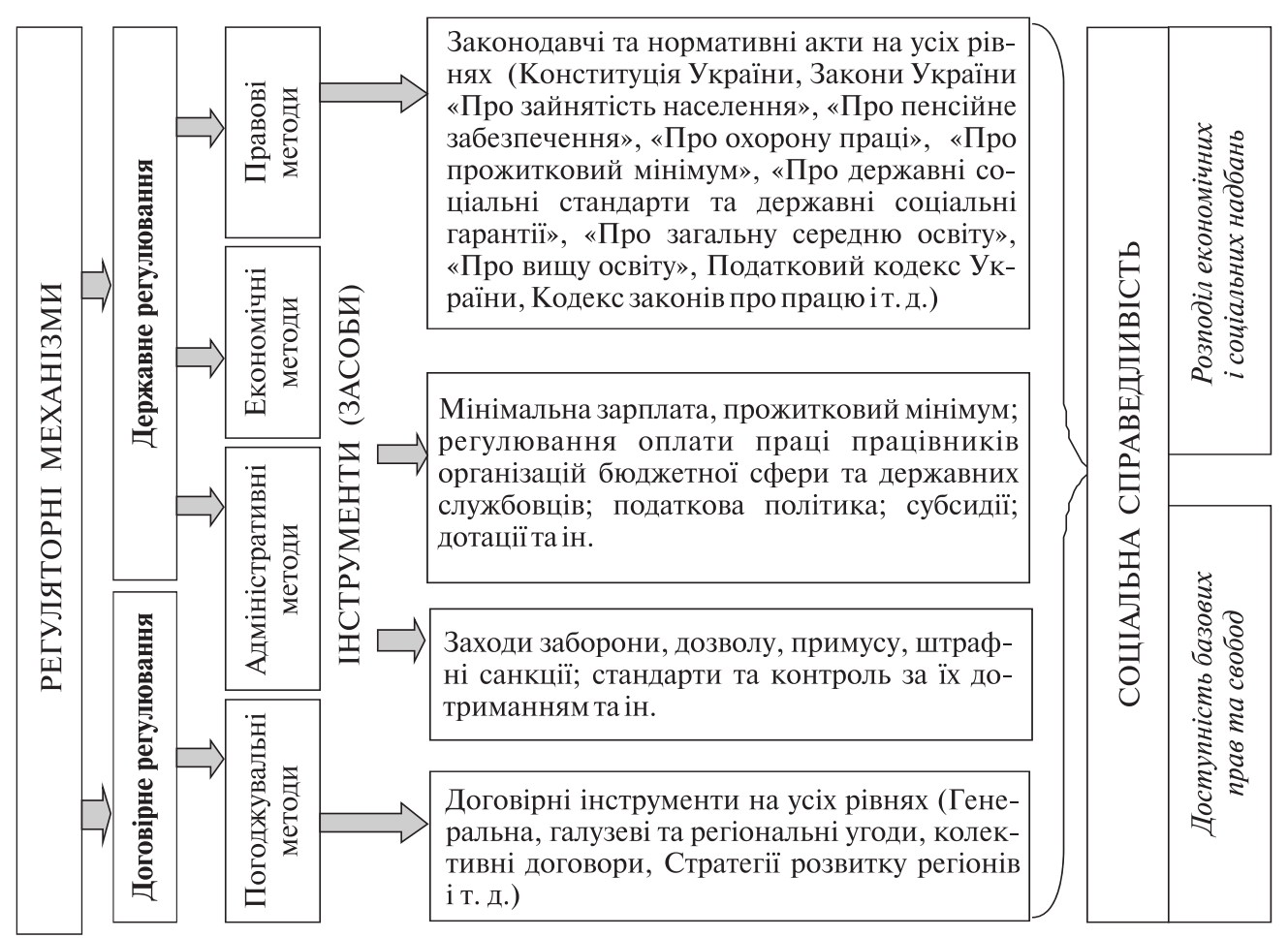

\section{Рис. 3. Регуляторні механізми забезпечення соціальної справедливості}

Джерело: розробка авторів.

Висновки. Теорія справедливості на сьогодні має багато послідовників та аргументів її прикладної спроможності. Поєднуючи фундаментальні засади теорії справедливості та сучасні інструменти оцінки ії окремих факторів, автори пропонують удосконалити вимірювання справедливості на основі агрегатного індексу, складові якого обумовлені логікою розуміння справедливості. По-перше, він обов'язково враховує дотримання базових прав людини у вигляді мінімальних соціальних стандартів гарантування рівня життя. По-друге, оскільки людський розвиток зумовлює прагнення до вищого рівня справедливості, другою складовою є індекс, що дає змогу вимірювати досягнутий рівень справедливості у процесах розподілу відносно «еталонних» показників найбільш справедливих та успішних країн або будь-яких інших порівнюваних соціальних груп. Здійснені розрахунки рівня соціальної справедливості за обгрунтованою у цій роботі методикою дають підстави для висновків про теоретичну та прикладну застосовність цього інструментарію оцінки, оскільки за всіма підходами до встановлення вагових коефіцієнтів часткових індексів підтверджено лідерство країн, що мають найбільші досягнення в економічній та соціальній сфері. Показано, що індекс соціальної справедливості повною мірою характеризує якість соціального середовища формування економічних інтересів у суспільстві на основі врахування ефективності обох процесів, визначальних для сприйняття суспільних відносин як соціально справедливих: дотримання фундаментальних прав, а також забезпечення ефективності відносин розподілу соціально-економічних надбань. Важливим прикладним аспектом вимірювання соціальної справедливості є можливість 
виявлення резервів на основі порівнянь з лідером за інтегральним та частковими індексами. Здійснені нами порівняння дають змогу визначити «відставання» від лідера (у дослідженій групі країн - Фінляндія) та резерви покращення кожної складової забезпечення справедливості відносно еталонного значення $(1,0)$, на основі чого можна обгрунтовувати вибір пріоритетних напрямів дотримання базових прав людини та удосконалення відносин розподілу у суспільстві.

Розуміння справедливості апріорі обтяжене суб'єктивними факторами, але в цивілізованому світі потреба забезпечення хоча б базової справедливості у вигляді безумовного гарантування та виконання прав людини не викликає сумнівів. Співвідношення вагомості двох субіндексів, як і методика їх розрахунку, є принциповою пропозицією авторів, яка потребує продовження робіт, у тому числі у наукових працях колег, зацікавлених у дослідженнях справедливості.

\section{ЛІТЕРАТУРА}

1. UN General Assembly (2007). Resolution No 62/10 [Електронний ресурс]. - Режим доступу : http://www.un.org/en/ga/search/view_doc.asp?symbol=A/RES/62/10 (дата звернення: 15.02.2018).

2. International Labour Organization (2008). ILO Declaration on Social Justice for a Fair Globalization [Електронний ресурс]. - Режим доступу : http://www.ilo.org/global/about-the-ilo/mission-andobjectives/WCMS_099766/lang--en/index.htm (дата звернення: 15.02.2018).

3. Rawls J.A. Theory of Justice. - Cambridge, Mass.: The Belknap Press of Harvard University Press, 1971. $-607 \mathrm{p}$.

4. UN General Assembly, (1948). Universal declaration of human rights [Електронний ресурс]. -Режим доступу : http://www.jus.uio.no/lm/un.universal.declaration.of.human.rights.1948/portrait.a4.pdf (дата звернення: 15.02.2018).

5. Stiglitz J.E. The Roaring Nineties: Seeds of Destruction Hardcover. - London: Penguin, 2003. $389 \mathrm{p}$.

6. Пирогов Г., Ефимов Б. Социальная справедливость в экономике и социологии // Золотой Лев. - № 129-130 [Електронний ресурс]. - Режим доступу : http://www.zlev.ru/129/ 129_4.htm (дата звернення: 15.02.2018).

7. Львов Д.С. Справедливость и духовный мир человека // Политический журнал. - 2007. № 7. - С.16-28.

8. Грішнова О.А., Мішук Г.Ю., Олійник О.О. Соціальна відповідальність у трудових відносинах: теорія, практика, регулювання ризиків. - Рівне, 2014. - 216 с.

9. Сталий людський розвиток: забезпечення справедливості: Національна доповідь / кер. авт. колективу Е.М. Лібанова / Інститут демографії та соціальних досліджень ім. М.В. Птухи НАН України. - Умань: Візаві, 2012. - 412 с.

10. Гриненко А.М. Соціальна справедливість як ключовий принцип у реалізації соціальної політики держави // Наукові праці [Чорноморського державного університету ім. П. Могили комплексу «Києво-Могилянська академія»]. Сер.: Педагогіка. - 2009. - Т. 112, Вип. 99. - С. 104-107. [Електронний ресурс]. -Режим доступу : http://nbuv.gov.ua/UJRN/Npchduped_2009_112_99_19 (дата звернення: 15.02.2018).

11. Новіков В.М., Семенов В.В. Досягнення справедливості як умова соціогуманітарного розвитку // Демографія та соціальна економіка. - 2013. - № 2. - С. 40-49. doi: https://doi.org/10.15407/ dse2013.02.040.

12. WEF (2016-2017). Global Competitiveness Report [Електронний ресурс]. - Режим доступу : http://www3.weforum.org/docs/GCR2016-2017/05FullReport/TheGlobalCompetitiveness Report2016-2017_FINAL.pdf (дата звернення: 15.02.2018).

13. Mishchuk $\bar{H}$., Samoliuk N., Bilan $Y$. Income inequality and its consequences within the framework of social justice // Problems of Sustainable Development Journal. - 2018. - № 2.

14. IEF (2016). Index of Economic Freedom [Електронний ресурс]. - Режим доступу : http://www. heritage.org/index/pdf/2016/book/index_2016.pdf (дата звернення: 15.02.2018). 
15. UNDP (2016). Human Development Report [Електронний ресурс]. - Режим доступу : http://hdr. undp.org/sites/default/files/2016_human_development_report.pdf (дата звернення: 15.02.2018).

16. Hospers $J$. The libertarian manifesto. Morality in Practice. - 2003. - P. 21-27.

\section{REFERENCES}

1. Resolution No. 62/10 (2007). UN General Assembly. un.org. Retrieved from http://www.un.org/en/ $\mathrm{ga} /$ search/view_doc.asp?symbol=A/RES/62/10.

2. ILO Declaration on Social Justice for a Fair Globalization (2008). International Labour Organization. ilo.org. Retrieved from http://www.ilo.org/global/about-the-ilo/mission-and-objectives/WCMS 099766/lang--en/index.htm

3. Rawls, J.A. (1971). Theory of Justice. Cambridge, Mass.: The Belknap Press of Harvard University Press.

4. Universal declaration of human rights (1948). UN General Assembly.jus.uio.no. Retrieved from http:// www.jus.uio.no/lm/un.universal.declaration.of.human.rights.1948/portrait.a4.pdf

5. Stiglitz, J.E. (2003). The Roaring Nineties: Seeds of Destruction Hardcover. Allen Lane/Penguin; London, 389.

6. Pirogov, G., \& Efimov, B. Sotsialnaya spravedlivost v ekonomike i sotsiologii [Social Justice in Economics and Sociology]. Zolotoy Lev - Golden Lion, 129-130. zlev.ru. Retrieved from http://www.zlev. ru/129/129_4.htm [in Russian].

7. Lvov, D.S. (2007). Spravedlivost i duhovnyiy mir cheloveka [Justice and the spiritual world of man]. Politicheskiy jurnal - Political magazine, 7 [in Russian].

8. Hrishnova, O.A., Mishchuk, H.Yu., \& Oliynyk, O.O. (2014). Sotsialna vidpovidalnist u trudovykh vidnosynakh: teoriia, praktyka, rehuliuvannia ryzykiv [Social responsibility in labor relations: theory, practice, risk management]. Rivne : NUVHP [in Ukrainian].

9. Libanova, E.M. (Eds.). (2012). Stalyi liudskyi rozvytok: zabezpechennia spravedlyvosti [Sustainable Human Development: Ensuring Justice] Instytut demohrafii ta sotsialnykh doslidzhen im. M.V. Ptukhy. Uman : Vizavi [in Ukrainian].

10. Hrynenko, A.M. (2009). Sotsialna spravedlyvist yak kliuchovyi pryntsyp u realizatsii sotsialnoi polityky derzhavy [Social justice as a key principle in implementing social policy of the state]. Scientific works Black Sea State University named after. P. Tombs of the complex «Kyiv-Mohyla Academy», 112 (99), 104-107 nbuv.gov.ua. Retrieved from: http://nbuv.gov.ua/UJRN/Npchduped_2009_112_99_19 [in Ukrainian].

11. Novikov, V.M. (2013). Dosiahnennia spravedlyvosti yak umova sotsiohumanitarnoho rozvytku [Achievement of justice as a condition of socio-human development]. Demohrafiia ta sotsialna ekonomika - Demography and Social Economy, 2, 40-49. - doi: https://doi.org/10.15407/dse2013.02.040 [in Ukrainian].

12. Global Competitiveness Report 2016-2017 (2017). WEF. weforum.org. Retrieved from: http://www3. weforum.org/docs/GCR2016-2017/05FullReport/TheGlobalCompetitiveness Report2016-2017 FINAL.pdf [in English].

13. Mishchuk, H., Samoliuk, N., \& Bilan, Y. (2018). Income inequality and its consequences within the framework of social justice. Problems of Sustainable Development Journal, 2.

14. Index of Economic Freedom (2016). IEF. heritage.org.: Retrieved from http://www.heritage.org/ index/pdf/2016/book/index_2016.pdf.

15. Human Development Report (2016). UNDP. hdr.undp.org. Retrieved from: http://hdr.undp.org/sites/ default/files/2016_human_development_report.pdf.

16. Hospers, J. (2003). The libertarian manifesto. Morality in Practice, 21-27.

Стаття надійшла до редакції 26.02.2018. 